
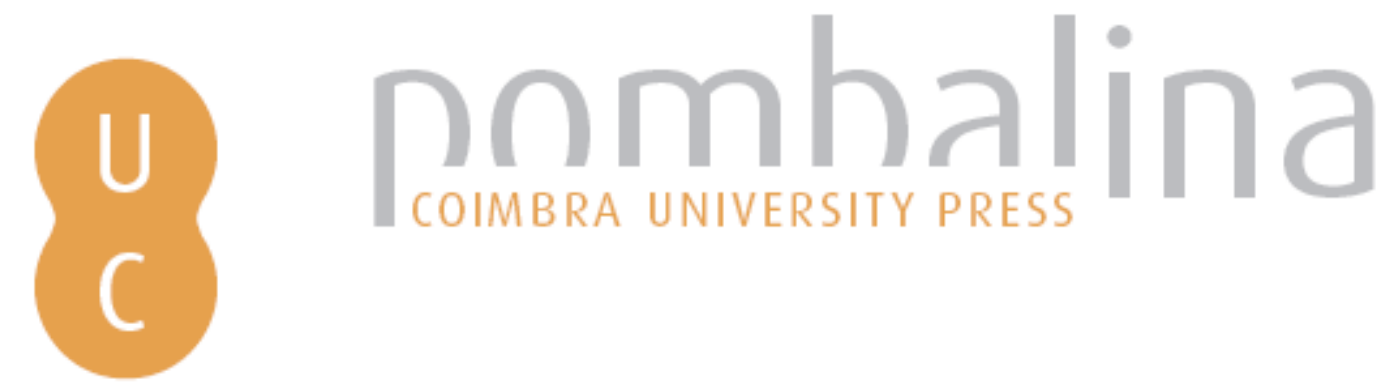

\title{
Tradition and Identity in Lycophron
}

\author{
Autor(es): Deserto, Jorge
}
Edições Afrontamento; CITCEM - Centro de Investigação
Publicado por: Transdisciplinar "Cultura, Espaço e Memória»; Centro de Estudos
Clássicos e Humanísticos; Alexandria University; Imprensa da Universidade de Coimbra

$\begin{array}{ll}\text { URL } & \text { URI:http://hdl.handle.net/10316.2/36173 } \\ \text { persistente: } & \text { DOI:http://dx.doi.org/10.14195/978-989-26-0966-9_12 }\end{array}$

Accessed : $\quad$ 26-Apr-2023 08:50:40

A navegação consulta e descarregamento dos títulos inseridos nas Bibliotecas Digitais UC Digitalis, UC Pombalina e UC Impactum, pressupõem a aceitação plena e sem reservas dos Termos e Condições de Uso destas Bibliotecas Digitais, disponíveis em https://digitalis.uc.pt/pt-pt/termos.

Conforme exposto nos referidos Termos e Condições de Uso, o descarregamento de títulos de acesso restrito requer uma licença válida de autorização devendo o utilizador aceder ao(s) documento(s) a partir de um endereço de IP da instituição detentora da supramencionada licença.

Ao utilizador é apenas permitido o descarregamento para uso pessoal, pelo que o emprego do(s) título(s) descarregado(s) para outro fim, designadamente comercial, carece de autorização do respetivo autor ou editor da obra.

Na medida em que todas as obras da UC Digitalis se encontram protegidas pelo Código do Direito de Autor e Direitos Conexos e demais legislação aplicável, toda a cópia, parcial ou total, deste documento, nos casos em que é legalmente admitida, deverá conter ou fazer-se acompanhar por este aviso.

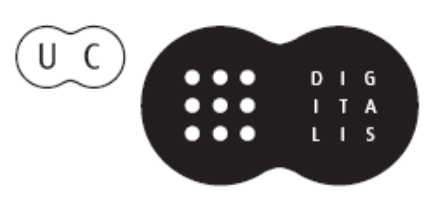




\title{
TRADITION AND IDENTITY IN LYCOPHRON
}

\author{
JORGE DESERTO
}

University of Oporto. Centro de Estudos Clássicos e Humanísticos (University of Coimbra).

\begin{abstract}
Lycophron's Alexandra has been called an «obscure poem». Through the difficulties of an enigmatic text that raises questions about its author and date, this paper deals with two fundamental issues: first, if it is possible to call Alexandra a drama and set a parallel between this work and $5^{\text {th }}$-century Athenian tragedy. Second, how Lycophron deals with the long and well established identity of his characters, and in particular with the identity of Cassandra, whose words we hear throughout the poem. A long mythological tradition together with an enigmatic and elusive text - they both constitute a strange and challenging paradox. A brief analysis of Lycophron's "odyssey» (1l. 648-819) shows how the poet manages to achieve equilibrium while dealing with these two themes: tradition and identity.
\end{abstract}

It is undoubtedly a challenge to write about a work that requires the use of an instruction book. Under normal circumstances, we find reasonable for this to happen with a domestic appliance: urban mythology is full of stories in which the act of programming a VCR dangerously resembles a descent in hell. But it will be reason to look with suspicion, and even fear, at a literary work that only can be clearly understood if we take into account the commentaries left by the scholiasts. Now this is what systematically happens with Lycophron's Alexandra.

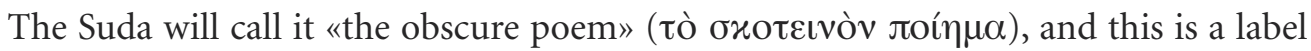
that has stuck to it. When we start reading any work about this poem, we often find, more 
or less vividly expressed, the disenchantment of its author, as if he had engaged in a task far beyond the forces of a mortal. In 1901, in the early 20th century, Gildersleeve said: «Few scholars now-a-days read Lykophron and almost all who do read him claim a reward of merit by writing something about him» ${ }^{1}$. A century later, Elizabeth Kosmetatou ${ }^{2}$ opens her essay with the following words: "Lycophron's Alexandra remains the most obscure and enigmatic literary work of the Hellenistic period and indeed, it could be argued, of the entire Antiquity». Together with encouraging words like these, a bibliographical flow not quite copious, though constant. There is only one exception, also quite disturbing. In these early years of the 21st century, a group of French scholars has dedicated itself to the study of Lycophron, so that, between 2005 and 2008, were published in France four different translations of the Alexandra (including the one belonging to the Budé collection), along with several studies, some of them collective works ${ }^{3}$. I cannot find an explanation for such abundance. It does not represent, for sure, a sudden need for the French reader, anxious to know four different ways to decline the Alexandra into the language of Molière. In fact, however bizarre it may seem, this exception simply confirms the rule.

We may begin with a brief description of the poem. This is a relatively long text, consisting of 1474 iambic trimetre. Not far, in extension, from a Sophocles' tragedy ${ }^{4}$. It consists of the long account of a messenger, who presents to his king the words of the young prophetess Alexandra (i.e., Cassandra). In her speech she reveals in detail the fate of Troy, in the future conquered by the Greeks, but also the troubled return of the conqueror army, victim of divine wrath, due to the way Ajax attacked Priam's daughter, near the altar of Athena. The story then extends beyond the moment when Alexander manages to reunite Europe and Asia. According to Stephanie West ${ }^{5}$, we can find in the huge temporal scope of this action a topic that works as a common denominator: the rivalry between east and west. At least the formal structure is simple and clear: the first thirty lines present the messenger's introductory speech; after, up to line 1460, we ear the literal words of the princess - thus these 1430 lines correspond to the core of the poem itself; in the last fourteen lines, we go back to the words of the servant.

Two questions claim our attention when we look at the Alexandra-and both, in some way, relate to the theme of this paper, tradition and identity. On one hand, we have to discuss how this work fits into the dramatic tradition, if it actually does; on the other, the

\footnotetext{
${ }^{1}$ Apud WEST, 1984: 127-8.

${ }^{2}$ KOSMETATOU, 2000: 32.

${ }^{3}$ Translations: LAMBIN, 2005; HUMMEL, 2006; CHAUVIN, CUSSET, 2008; HURST, 2008. As an example of collective work see CUSSET, PRIOUX, 2009.

${ }^{4}$ It is almost the same verse number of Sophocles' Pholoctetes (1471). It exceeds in extent Ajax, Antigone and Trachiniae, but is shorter than Electraand both Oedipus. It can therefore be said, using Sophocles as a perfectly legitimate reference, that Alexandra has the average length of an Athenian tragedy.

${ }^{5}$ WEST, 2000: 154.
} 
problem of the authorship, an endless debate that, by some undeniable similarities, never ceases to remind us of the well-known Homeric Question.

Let us begin exactly by this point. After all, who wrote the Alexandra? The Lycophron to whom the poem is usually attributed was born in Chalcis at an imprecise date, probably between 330 and 320 B.C. Tragic author - the Suda attributes to him twenty-one different titles of tragedies - he was a member of the tragic Alexandrian Pleiad. It is possible that, within the context of the critical editions carried out in the Library, he was responsible for editing the comedy, and is assigned to him a treatise, in nine books, about comedy (Пr@i K $\omega \mu \omega เ \delta i \alpha \varsigma)$. He would have also composed a satiric drama entitled Menedemus. We speak thus of someone perfectly integrated in the literary world of Alexandria, who cannot be confused with any other author that we know having the same name.

If the biographical question seems peaceful - we must say nothing about Lycophron is completely peaceful - the problem arises from the text. Certain passages of the poem (particularly 1226-1280 and 1446-1450) seem to presuppose a knowledge of Roman power that would be quite unnatural at the time of an author as the Lycophron above. We can express this doubt (which already goes back to the ancient commentaries of Tzetzes) with the words chosen, in 1800, by a curious British reader, Charles James Fox (apud West, 1984: 127), which shows himself amazed while reading «the part where he speaks of the Romans in a manner that could not be possible for one who lived in the time of Ptolemy Philadelphus, that is, even before the Punic war».

At the beginning of the first passage (1226-1231), Cassandra speaks of her descen-

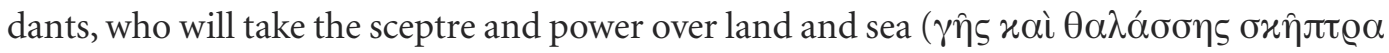

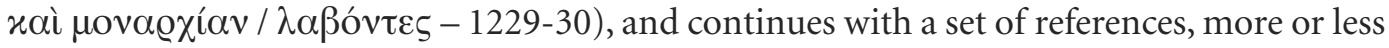
cryptic to the voyage of Aeneas and to the first Roman myths. Either the nature of the power thus described, either the extension and the centrality of the reference to the Romans, in this passage, seem quite not adequate to the period where the tradition places that Lycophron of Chalcis, according to the biographical data presented by the Suda.

To this we may add, ahead in the poem (1446-1450), the reference to a descendant, a

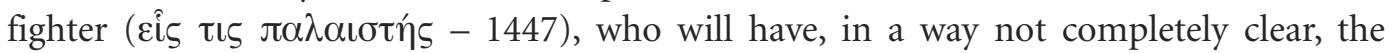
domain over the Greek land, and that some scholars (the so-called radical unitarians) relate to Titus Quintus Flaminius and to the victory he got over Philip V of Macedonia in 197-6 B.C.

To these perplexities - here presented perhaps too briefly - experts have reacted with remarkable harmony. Basically, they agree to disagree. In general, we can speak of three major groups: first, the analytics, who defend that the poem was composed by more than one hand, even if the core may be attributed to the Lycophron acknowledged by the tradi$\operatorname{tion}^{6}$; the radical unitarians maintain that the whole poem was composed later, in the first

\footnotetext{
${ }^{6}$ See WEST, 1984 and 2000; HUNTER, 2004: 437-439.
} 
half on the 2nd century B.C., by an author completely different from the Lycophron of Chalcis $^{7}$; finally, the conservative unitarians argue that all those problems do not prevent the attribution to the traditional author, considering, among other arguments, the elusive and enigmatic nature of the text ${ }^{8}$.

Unless new data arise that miraculously solve this question, the discussion is bound to continue. It is fair to say that this problem seems to be sought by the text itself: a work that is difficult to read and that assumes this difficulty as a deliberate purpose, even if that is not the only reason for the enigmatic textual organization, is subject to a multiplicity of readings and to the controversy that emerges from it. It should be noted, also, in relation to this particular question about the date of composition and the puzzling passages mentioned above, that our position, in the present, knowing all the subsequent events, clearly may divert our reading, even unintentionally. After all, it is easier for us to read as factual what, in the text, could just be allusive. My purpose, however, is just to acknowledge this difficulty and to stress how this text presents, even before we start reading it, a severe problem of identity, which naturally conditions the way we cope with it.

It will be more useful to question how this work fits into the dramatic tradition. The question is simple: is Lycophron's Alexandra a drama? Can we establish some sort of connection between this poem and the tragedy of the 5th century B.C.? One immediate answer will report some points of contact, such as the use of iambic trimester or the presence of a dramatic device as the messenger speech. But these are the same aspects that clearly mark the difference. Greek tragedy never reduced itself to a sequence of verses in iambic trimester - and a highly regular one, as is the case in the Alexandra-, even if that is, as we know, the metric form prevailing in the episodes. Tragedy is poetry marked by its rhythmic variety and whether this variety may be present in the episodes, it becomes more evident when we consider the choral odes, and when we remember how the harmony of the tragic spectacle also relies on the richness of alternating episodes and stasima. On the other hand, if the messenger speech is an almost mandatory part of Greek tragedy, Alexandra seems to reduce the entire tragedy to a messenger scene, or, looking the other way around, seems to expand a messenger scene as to become an entire drama. In this obvious lack of balance, what is clearly visible are not the signs of proximity to the Athenian drama, but what prevents us from really being in face of a true dramatic work.

We should also have in mind that a messenger-speech is, in a drama, the very less dramatic element. Strictly speaking it is a narrative incision in the dramatic tissue, introducing a character which does not effectively act, only reports events that took place elsewhere. Somehow the use of a messenger is a way to get around a limitation of drama, incapable of representing plausibly more complex events (death, for example, or episodes of a fantastic

\footnotetext{
${ }^{7}$ See ZIEGLER, 1969; JOSIFOVIC, 1968; GIGANTE LANZARA, 2000: 19-21.

${ }^{8}$ See MOMIGLIANO, 1942 or HURST, 2008.
} 
nature, involving many figures, as battles). There are actions that become more powerful when expressed in words, at least if we cannot use special effects such as those modern cinema industry can use nowadays. The messenger-speech scene bypasses a limitation of drama by making use of a device non dramatic in essence but narrative, a device which points us to epic, not to drama. Somehow, making this choice, Lycophron uses a sort of drama simulacrum, a façade, but what he does put inside it has a nature completely different from what we expect of a drama.

The very extent of the poem confirms the above statement. There is, in the messenger-speech of Greek drama, a principle of restraint - we can relate it with that kind of concentration which defines drama as a whole; a messenger's speech singles out an event (whether we are talking about the death of Eurydice or Jocasta, or how the Guard tells us the homage at the tomb of Polyneices); in the Alexandra this messenger's speech extends itself in time and space, goes through centuries, is longer than most epic poems. If we think it better, the messenger-speech is just a cover, concealing something else, closer to epic than to drama.

We might also impose to Alexandra the test of representation. Greek tragedies from 5th century B.C. are still staged today and, in most cases, we see excellent dramatic performances, as it has been demonstrated by several recent examples, in Portugal and abroad $^{9}$. If we try the same with Lycophron's poem, certainly we have to store it in the closet reserved to the therapeutic category of sleep inducers. A long monologue, a single character, a text hard to interpret, all these elements would be able to discourage even the most benevolent public. Moreover, according to Stephanie $\mathrm{West}^{10}$, it seems reasonable to think that, even when it was created, this work was not aimed to any kind of public presentation. If anything, some selected parts could be recited in front of a chosen audience, a hypothesis that the episodic structure of the text encourages. But it is equally true that, at the third or 2nd century B.C., it would be possible to enjoy this poem through silent reading. All this here is my main point - leads us away from drama and from the spectacular dimension necessarily associated to it.

Let us now comment on the selection and presentation of characters. The only voice we hear is that of a servant, telling to a $\mathrm{king}^{11}$, in accordance to received orders, the words

\footnotetext{
${ }^{9}$ I just point two recent examples, Antigone and Oedipus Rex, both presented in Oporto, the first in 2010, the last in 2012. Recorded here for a question of proximity, both are clear evidence of how Greek tragedy may be attractive to the 21 st century audience.

10 WEST, 1984: 129.

${ }^{11}$ We notice, indirectly, that this king is Priam (1. 19). This happens during the introductory words of the servant and not in the speech of the prophetess. So the use of a sinuous and allusive language is not exclusive of Cassandra. Lycophron did not bother to differentiate between the two segments of speech, to give an autonomous voice to the servant. Or - this second assumption is perhaps too far-fetched - Lycophron wants the servant's speech to be, from the beginning, contaminated by the dark words of the princess, those words this man is scrupulously prepared to repeat in a moment.
} 
of the king's daughter, Alexandra/Cassandra. The young woman remains in a secluded place, where her terrible words cannot spread the fear. Let us focus on these three figures.

In first place the silent and somehow absent king of Troy. He is the addressee of the message and the one that originates it. We may suppose him a silent listener, an invisible one, and, so, he may be taken as one of us, spectators or readers. If he is almost lost as a theatrical character, because of his absence, he gains an unexpected dimension, when we realize that Lycophron puts us exactly in the same position of Priam, facing, as he does, a challenging text, both by the calamities it predicts and by the difficulties of interpretation it arises.

As for the servant, this is, as we know, the kind of character that usually plays the role of messenger. The lack of importance of these figures allows us to focus on the message and not on who transmits it. As happens, usually, with the anonymous characters of Greek drama, the absence of a mythical tradition leaves a large margin in terms of characterization: a servant may be an example of fidelity and devotion, as he use to see in Euripides' drama, may produce some morally engaged considerations, more or less surprising or daring. But even in these cases, the message outweighs the messenger and we tend to forget him as a character. However, if this particular servant is just a voice that reproduces Cassandra's words, the truth is that he is not Cassandra and that, as we will see shortly, makes a lot of difference. We may add another aspect that modifies and distinguishes this specific messengers' speech: it is not exactly a narrative and even less a speech produced by the speaker himself. With the exception of a few verses that constitute the initial and final frame, the servant reproduces - we understand he makes it with absolute accuracy - the words of the princess. This servant is therefore a borrowed voice, a kind of ventriloquist's dummy trough which Cassandra speaks. This conditions the messenger and his characterization, but also the way we relate with Cassandra as a character and even more as a character with a long literary tradition.

There is a deliberate choice in hearing Cassandra through a deferred voice. This does not seem to happen by chance. If we think of this character in Greek drama, we easily acknowledge a powerful tradition concerning the presence of Cassandra on stage: we all remember without effort two scenes, in Aeschylus' Agamemnon (1l. 1035-1330) and in Euripides' Trojan Women (11.292-461). In either of them, even taking into account the natural differences, two key elements stand out: the spectacle of the dramatic speech produced by a character under possession, and the dramatic presence, equally disturbing, of the prophetic words, presenting a terrifying image of the future. It is not necessary to insist on how these two elements influence mutually, how the prophetic discourse gains intensity through the disturbance of the figure that delivers it and, and how, at the same time, it is the prophetic ability that leads us to a deeper involvement with the disturbance of the character. Brake this connection causes a significant deviation from a traditional pattern, that has already a great amount of strength. Tradition cannot easily be ignored. Lycophron does 
not follow the path we could expect regarding to Cassandra as a dramatic character. By giving her another voice, allowing us to access to her words but not to her presence, the poet runs away from a dramatic dimension, the princess becoming just a shadow without effective dramatic consistency. To remove the dramatic effect is a way to decaffeinate the drama, to put its purpose in a different place, creating an intellectual game, designed for a scholar audience who takes pleasure in deciphering puzzles. So, renouncing Cassandra as a character helps to remove this poem away from drama and contributes to make it something else. More difficult is to know exactly what that new thing is.

The truth is that of the two elements listed above (the prophetic figure, the prophetic speech) one of them still remains: the core of the text is the prophetic word and, in this particular, nothing seems more adequate. The prophetic word is uncertain, its meaning is never completely seen, it lives in the middle of shadows and fog, and it raises more questions than answers. Nothing more appropriate to a deciphering exercise than a text that is by definition difficult and challenging. And Lycophron takes things even further by putting us in front of a messenger that reproduces prophecies he himself does not understand; that brings us, spectators, closer to that puzzled voice delivering the speech. So we must recognize that the prophetic discourse, with its own very nature, is perfectly adapted to the purposes of Lycophron, and becomes, unlike what happens with the choice of characters, dramatically relevant and in accordance with tradition.

In this balance between tradition and obscurity a paradox emerges to which we must pay attention. Cassandra's prophecy deals with a set of well-known events, the fate of Troy, the troubled return home of the Greek heroes. This knowledge proves to be a key element in the work of deciphering a text admittedly hard to understand. It is the very need of not to completely eliminate the chances of understanding that leads inevitably to a point in which the relationship with the tradition has to be more conservative. It is not possible to subvert excessively a traditional version while using a cryptic speech - even such speech requires some opening to intelligibility. Lycophron's text is forced to move on this unstable path between concealment and recognition, and the way the poet manages this balance has obvious consequences on the efficacy of the text, or rather on the efficacy on the challenge it constitutes.

It is time now to return to Cassandra. Beyond her deletion as a dramatic character, and the obvious influence of that deletion on our relation with the poem, we cannot forget what we hear are the words of the Trojan princess. It is important to know if the way tradition is presented takes into account the character that, indirectly, produces the words, if Cassandra's prophecies, despite her absence as character on stage, represent a voice of her own.

A particularly suitable passage to deal with this question is the long "odyssey» of Lycophron, the central part of the poem (1l. 648-819), in which Cassandra predicts the return of Odysseus. I do not need do stress the importance of the Homeric Odyssey throughout Greek culture, its presence as a referential text, known to everyone. Its rooted- 
ness, its dissemination, its influence makes even a more obvious dissonance if someone tries to present an alternative version. But we also know Greek myths are continually subject to change. Some alternative versions did exist and they also become shared territory. One of them, which may have served as inspiration to Lycophron, is the speech where Cassandra foretells the return of Odysseus in Euripides' Trojan Women (1l. 435-443). There, Hecuba's daughter emphasizes the sufferings of the hero during his long journey back home and strategically eludes any reference to a successful outcome after arriving to Ithaca, just saying, before changing the subject, that, also at home, Odysseus will find «pain and suffering». No mention to the revenge, to the death of the Suitors, to Penelope. So already in Euripides the «odyssey», according to Cassandra, only focuses on the sufferings of the hero, an option quite consistent with the negative image Odysseus has in this tragedy (and in Greek tragedy in general, we must say). Lycophron's version cannot be said properly original. But, as we have already seen, complete originality and puzzles do not get along quite well.

In the Alexandra the negative image associated to Odysseus' nostos is part of a broader narrative pattern. All the punishment that falls on the return of the Greeks is presented as a just penalty for the offence on Cassandra, attacked by Ajax under the protection of Athena's altar. This framework of punishment does not allow for exceptions and therefore also the Odyssey must be retold. While we are dealing with the return journey, the tradition has enough trials and tribulations, so the picture does not require substantial changes. After the arrival to Ithaca, as we easily understand, the rewriting process must be more radical.

Odysseus' wanderings are presented to us in an episodic structure, a sequential pattern, always according with the enigmatic nature of the text. Thus, the narrative organization we know from Homer's Odyssey, a crescendo that slowly leads us, through many detours, up to a happy end, is diluted here by a simpler presentation, to which the obscurity of the text draws emotional weight. Surely the necessary recognition effect is attained due to the presence, identifiable enough, of the episodes known from Odysseus' nostos (Laestrygones, Cyclops, Circe, the Sirens, Scylla and Carybdis - even if some treated differently), creating a foil able to accommodate a less happy fate for Odysseus.

The signs of dissonance are, of course, more important, not only because of the way they differ from the Homeric version, but also because they represent an adaptation to the specific voice of Cassandra. I will address briefly three examples that seem to me sufficiently illustrative.

Let us look to the first word. We all remember the word (óv $\varrho \alpha)$ that initiates the Homeric text and how this «man» becomes the centre of the whole poem. Lycophron chooses to begin his «odyssey» with toús («they», 1. 648), and we understand he means Odysseus' comrades; only a few lines later he says that only one ("̌v $\alpha, 1.657)$ of these men, Odysseus himself, has survived from that terrible nostos. This ingenious reversal of Odyssey's proposition (cf. Od. 1. 1-9) can, in a single stroke, devalue Odysseus' role and 
remove him from a central place, and, furthermore, turn our attention to those men whose return the lord of Ithaca failed to ensure ${ }^{12}$. Obviously this effect is only achieved if we keep in mind - but how could we not to? - the first lines of the Odyssey.

The second example concerns the episode of the Sirens, quite important in Homeric narrative, but equally important because of its resonance throughout time. It is particularly relevant in Lycophron, both by its length (11. 712-737) and by the way it occupies a central place in this specific «odyssey». The emphasis in Lycophron does not concern the magic spell of their song neither the stratagem that allows Odysseus to hear it. Naturally all this is in the memory of his readers, and Lycophron knows it. That is why he can so clearly depart from the Homeric story and almost erase Odysseus from his version. The focus of the episode, in Lycophron's poem, rests on how the Sirens - and their memory - came to occupy the landscape of southern Italy, the region where the poet locates this tale. We cannot find here the Sirens story as told by Homer, Cassandra takes up the episode from its Homeric ending and extends it in time for the following centuries. So the first punishment of Odysseus, in this episode, is how he almost disappears from it. The brief presence that still remains constitutes the second punishment, as the text essentially emphasizes the death of the Sirens. They have took their own lives, unable to bear the suffering due to the failure of the spell cast on Odysseus. The connection between this death and the king of Ithaca, evident in the verbal form that opens the episode ( $x \tau \varepsilon v \varepsilon \hat{\imath}$ - «he will kill», 1. 712), stands as an accusation, in a narrative sequence where the metis of the hero fades away, making way for a man who, along his journey, continues to spread the seed of death - and, without effort, we are invited to connect the death of the comrades, evoked at the outset of the odyssey's episode, with this other moment: after all, and this is the point, finding Odysseus is to find death.

The third example concerns the return to Ithaca. We all know how, in the Odyssey, this moment is long and carefully prepared. We wait a long time, the action slips back and forward, and finally we see Odysseus arm the bow and massacre the Suitors. And we have to wait even more to witness the recognition between husband and wife. What strikes us first in the Alexandra is the brevity of the episode (just 11. 768-778), and, secondly, the avoidance of all elements that construct the narrative strategy of Homer's poem. Odysseus will return to find all events already accomplished. He has no intervention, becoming a mere spectator of his palace's ruin and of the betrayal of his wife. What we see in quick glances, always twisting, as is usual in the language of this poem, is the palace handed over to the appetite

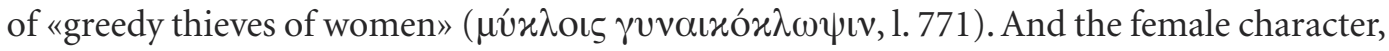

\footnotetext{
12 It is notorious how the Odyssey's author, in these opening lines, underlines that the death of Odysseus' comrades was caused by their foolishness, disobeying the order of their leader and eating the cattle of the Sun. This justification does not explain the death of most of the man that sailed with Odysseus from Troy. But the purpose is to point the uniqueness of that «man» who managed to escape from the traps others did not avoid. Cf. POWELL, 2004: 115-117. This concern, of course, is totally absent from Lycophron's work.
} 
the lady of the house, is called $\beta \alpha \sigma \sigma \alpha ́ \varrho \alpha$ («fox without shame», 771), and is said to be «for-

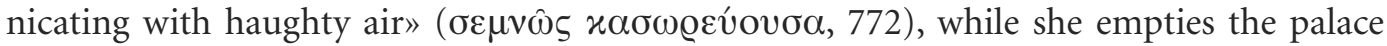
with feasts that exhaust Odysseus' properties. It is very brief this portrait of Penelope, but extremely eloquent in its hardness. We understand why Lycophron is so brief. Surely, if we think in Cassandra's point of view, it makes no sense that Odysseus had, waiting for him, a virtuous and faithful wife. But, on the other hand, fidelity is almost a second skin to Penelope, so her negative image is a point that Lycophron was not interested to stress. To draw Penelope in contradiction to her traditional portrait is fully consistent with the view of the Trojan princess, but only works properly as small detail in a larger picture. Giving it more emphasis could easily distort the picture itself, and develop some kind of resistance from those who hear the story.

The injuries and suffering that Odysseus receives inside his own home - we know it well from the Homeric text, Lycophron mentions it at (11.774-778) - are not a difficult stage before victory, but the very punishment of Odysseus, and not designed to end at this moment. The return to Ithaca is just a stage in the suffering of Odysseus, a man intended to continue wandering and die later at the hands of his son Telegonus - according to the version of the Telegony, much more appropriated to Cassandra's point of view. The final lines of Lycophron's «odyssey» present Odysseus as a man who dies after a life of constant suffering. He should have been much happier in his own land, had he succeeded to avoid war, without seeing denounced the ruse of his feigned madness. The general idea is that Odysseus as completely wastes his life.

One of the most impressive aspects in Lycophron's version of Odysseus' nostos is how the hero sees his role diminished. The story of his actions pays more attention to the fatal consequences they cause than to the value or excellence of the man who practices them. We can say that, without leaving his enigmatic speech, Lycophron is careful to adapt Odyssey's tradition to the particular voice that speaks here.

Lycophron's Alexandra is a very strange object. We may think of it as a drama, but we cannot find here the main characteristics of a theatrical play - and those we find are particularly distorted. As a literary work, Alexandra clearly lacks identity and must remain an odd and unclassifiable poem. We must say, however, that Lycophron tried to fit the tradition to Cassandra's character and situation. By saving Cassandra's identity he has saved - or at least tried to - the identity of the work itself. And, even unwillingly, we may become seduced by these strange and sinuous words. 